\title{
Roviny novodobé lužickosrbské etnické identity
}

\author{
Leoš Šatava
}

DOI: 10.21104/CL.2016.3.05

\section{Levels of modern-era Sorbian ethnic identity}

\begin{abstract}
The text concentrates on issues concerning the beginnings, development and current situation of the Sorbian ethnicity and ethnic identity in the region of Lusatia (Germany) from 1800 to the present. The given phenomenon is observed throughout the course of the 19th century which: 1) accelerated the transformation of Sorbs into the modern era ethnic group, enabling them to undergo a relatively successful "national revival"; 2) the same period, however, saw the acceleration of the language and ethnic assimilation (Germanization). Furthermore, attention is paid to the development, specific features, quests, possibilities and limits in the field of Sorbian ethnic consciousness in the 20th and 21st centuries; emphasis is laid on the present-day situation. Closer analyses and ensuing interpretations focus on social and psychological factors of the given problem range, as well as on political connotations. A dichotomous situation between the primordial and (post) modernist approaches to understanding ethnicity in Lusatia is also commented on in detail. Finally, the role of Sorbian elements as the common denominator of Lusatian regionalism is dealt with as well.
\end{abstract}

Keywords Sorbs, Sorbian language, Lusatia, ethnic identity, concepts of ethnicity, regional identity.

Contact Prof. PhDr. Leoš Šatava, CSc., Katedra etnológie a mimoeurópskych štúdií FF UCM, 91701 Trnava, Slovak Republic; e-mail: Isatava@tiscali.cz.

Jak citovat / How to cite Šatava, Leoš. (2016). Roviny novodobé lužickosrbské etnické identity. Český lid 103, 419-437. doi:http://dx.doi.org/10.21104/CL.2016.3.05 


\section{Úvodem}

Etnický a jazykový vývoj Lužických Srbů od roku 1800 až do současnosti je nosným př́kladem na poli studia etnicity/nacionalismu či identit. V mnohém se sice jedná o klasický model „národního hnutí malého evropského národa“ (Hroch 1986), v daném kontextu lze však nalézt i řadu přesahů a osobitostí. Také mnohé ze souvisejících otázek (jako: jsou Lužičtí Srbové „národem“? jedná se o jedno etnikum hovořící dvěma jazyky? - jsou horno- a dolnolužická srbština samostatné jazyky, či dvě variety jedné řeči? - je možno být Lužickým Srbem bez znalosti lužické srbštiny?) zůstávají nedořešeny.

K aktuální etnojazykové situaci, respektive sebeidentifikaci Lužických Srbů existuje nemalé množství studií, vycházejících především z empirických pozorování a výzkumů (Dolowy-Rybińska 2011; Šatava 2005). Cílem následujícího textu není rozhojnit tyto práce, ale - v rozsahem nutně limitovaném podání - předestřít historické pozadí novodobé etnické a jazykové emancipace a současné situace jednoho z nejmenších slovanských etnik. ${ }^{1}$

\section{9. století: počátky, vývoj, tendence}

Zásadní společenské změny přelomu 18. a 19. století nezůstaly bez odezvy ani v regionech Horní a Dolní Lužice, integrovaných v té době do rámce Saska a Pruska.

Specifikem oblasti Lužice tehdy bylo (a dodnes je) mnohasetleté soužití německé a slovanské (tj. lužickosrbské) složky. Slovanská populace sídlí v Lužici zřejmě od 8. století (Pjech 2014: 10-11); ${ }^{2}$ v 10. století upadla do područí otonské římské říše a od té doby byla vystavena německému politickému, kulturnímu a jazykovému vlivu. ${ }^{3}$ Germanizace zde však až do konce 18. století postupovala - na rozdíl od jiných, původně Slovany osídlených regionů v oblasti mezi Labem a Baltským mořem - spíše pozvolna. S výjimkou několika větších měst, ve kterých dominovalo německé měštanstvo, hovořila kolem roku 1800 většina obyvatelstva obou Lužic lužickosrbsky; velká část byla také dosud monolingvní. ${ }^{4}$

Společenské, politické a ekonomické změny, ke kterým od konce 18. století postupně docházelo, však dosavadní situaci proměnily. V daném kontextu je možno vymezit několik tematických rovin - především jazykovou a kulturní a dále etnickou, - které se ovšem do značné míry prolínají. 
1) Jazykový aspekt - stejně jako v mnoha dalších regionech Evropy obývaných obyvatelstvem etnicky a jazykově odlišným od vládnoucí či majoritní populace se i v Lužici postupně projevují snahy o změnu dosavadního postavení lužickosrbské populace. Duch osvícenství, v mnohém liberálnější a tolerantnější nežli předešlé doktríny, takovýmto snahám výrazně napomáhal. Zdůrazňování principu rozumu, humanity či rovnosti lidí se nutně promítly do vztahu řady tehdejších vzdělanců $\mathrm{k}$ dosud spíše přezíraným či opovrhovaným Lužickým Srbům (Šołta 1990: 122). ${ }^{5}$ Není tak překvapivé, že mezi prvními obhájci lužické srbštiny a jejích práv v tzv. jazykových obranách období „učeneckého zájmu“ (Hroch 1986: 64) byli ve druhé polovině 18. století mnohdy rodilí Němci (kupř. Karl Gottlob von Anton); tato generace byla brzy doplňována i lužickosrbskými autochtony (Zwahr 1997/98: 63).

Pohled na existenci slovanské složky v Lužici se v první polovině 19. století - spolu se sílícími panněmeckými snahami - postupně dále vyvíjel a vedl ke vzniku dvou zcela protikladných ideových táborů: radikálně germanizačního a naopak obranného. $V$ rámci druhého z nich přecházely osvícenecké a liberální (zčásti i revoluční) ideály plynule do prizmat romantismu. Lužičtí Srbové (stejně jako Češi, Slovinci a mnohé další dosud „spící“ středoevropské populace) vlastně pro svou potřebu adoptovali „herderovské“ vnímání národa jakožto pospolitosti stejného jazyka, vytvořené pro německé národní cíle, a začali se - do té doby v nebývalé míře - vymezovat právě jazykově. Tato linie vyvrcholila (v saské části Lužice) v roce 1848 v Lužickosrbské selské petici (Serbska burska peticija), obsahující řadu sociálních požadavků, a zejména v tzv. Matiční petici (Maćična peticija). ${ }^{6}$ Lužičtí Srbové tak v tomto revolučním roce poprvé vystoupili jako novodobá jazyková entita, v prodloužení však také jako entita etnická a zčásti i politická (Stawizny Serbow 1975, 2. díl: 106-107). ${ }^{7}$ Vedle jazykové sebeidentifikace a obrození lze však pro dané období vysledovat jistý ambivalentní paradox. Společenské výrobní změny, vyšší gramotnost v kontextu povinné školní docházky a také větší mobilita obyvatel totiž současně nastartovaly rovněž sílící proudy germanizace a jazykové asimilace - tj. trend postupného přechodu od lužickosrbského monolingvismu k bilingvismu, ústup lužickosrbského jazyka z řady domén a tendenci k plnému jazykovému posunu (language shift) směrem k němčině (Zwahr 1996: 144-145).

2) S jazykovou rovinou je nedílně provázána i rovina etnické sebeidentifikace a uvědomování. Ta se postupně začíná vydělovat $\mathrm{z}$ rovin zem-

5 Blíže k tématu viz Pollack 2012.

6 Matiční petice požadovala poprvé v dějinách pro lužickou srbštinu jazyková práva na poli školství a úředního styku a rovnoprávnost Lužických Srbů s Němci. Podepsalo ji 5000 představitelů domácností (zastupujících cca 40000 osob). 
ského či státního, tj. „saského“ a „pruského“, po roce 1871 i „celoněmeckého“ patriotismu (Zwahr 1996: 146).

Národně aktivní, vůdčí sociální vrstvou se u Lužických Srbů (na rozdíl od některých jiných evropských národů) nemohlo stát měštanstvo, ${ }^{8}$ nebot' tato skupina prakticky neexistovala. ${ }^{9}$ Alespoň zčásti ji však suplovali kněží, učitelé a movitější sedláci; tyto vrstvy stály i za zmíněnou Matiční peticí z roku 1848. Vzhledem k absenci novodobějších tradic státnosti Lužických Srbů bylo (v perenialistickém duchu) nutno symboly a atributy národní existence a etnické mobilizace hledat v dávné - bud' zcela bájné, či polomytické - době existence Pobaltských Slovanů před 10. stoletím. ${ }^{10}$

$\mathrm{Na}$ počátku 19. století nalezly tedy v Lužici plodnou půdu myšlenky osvícenství a (zejména německého) romantismu, velmi výrazně však doplněné ještě o další prvek: ideje a romantické vlivy slovanského světa. Novodobé národní uvědomění pozvolna vyrůstalo $\mathrm{z}$ poměrně nesourodé směsice a symbiózy sociálně revolučních nálad a osvícensko-romantických vlivů a vznikala tak ideologie zaměřená již nejen na obranu jazyka, ale i na sebepojetí Lužických Srbů jako svébytného, „neněmeckého“ etnika, přináležícího do velké rodiny slovanských národů (Stawizny Serbow 1975, 2. díl: 63-64). Právě přihlášení se k rozsáhlému Slovany obývanému světu (sahajícímu od střední Evropy až po břehy Tichého oceánu) mělo samozřejmě nejen symbolický, ale i výrazně vymezující a posilující význam. ${ }^{11}$ Takovéto deklarativní sebeodlišení od germánských etnik dalo Lužickým Srbům do jisté míry výhodu kupříkladu ve srovnání s emancipačním „národním“ hnutím Severních Frísů.

V daném kontextu měly mimořádný význam kontakty se sousedními Čechy, kteří se pro Lužické Srby stali vzorem na poli národního obrození a čímsi jako „starším bratrem“. Je však zřejmé, že lužickosrbské etnické vědomí se rodilo (vzhledem $\mathrm{k}$ řadě handicapů) pomalu a komplikovaně; zůstávalo také dlouho omezeno na relativně tenkou vrstvu národně aktivních osob (Šatava 2006b: 308). I když užití lužickosrbského jazyka bylo dál setrvačně přenášeno „mezigenerační štafetou“, zůstával „lid“ do značné míry etnicky nevyhraněn. U (jazykově) slovanské složky obyvatel Lužice tak mnohdy souběžně existovalo regionální vědomí, identifikace

9 Tato situace existovala i u řady jiných slovanských etnik, kupř́ikladu u Ukrajinců, Bělorusů či Kašubů.

10 Staří pohanští bozi (Svantovít, Triglav ad.), slovanská hradiště (včetně význačných míst mimo Lužici

- kupř. ostrov Rujána v Baltském moři), legendární král Miliduch, padlý v bitvě s uchvatitelskými Němci, bytosti a postavy z pohádek a pověstí, specifické folklorní zvyklosti aj. (Šatava 1992). 
s pojmy „Sas“ a „Prus“ i postupné etnické uvědomování se v slovanském duchu (Zwahr 1996: 146). ${ }^{12}$

Jiným dokladem zmíněného trendu „etnizace“ může být i vědecká rovina. Hornolužická vědecká společnost (Oberlausitzische Gesellschaft der Wissenschaften), založená v roce 1779 ve Zhořelci, byla zaměřena na regionální problematiku Horní Lužice - tedy včetně sorabistických témat, kterým poskytla významný organizační rámec (Stawizny Serbow 1975, 2. díl: 46-47). Postupně se však vytváŕí i vrstva lužickosrbské inteligence (studující a formující se hlavně v Lipsku, v Praze a ve Vratislavi); její členové pak v roce 1845 (resp. 1847) ${ }^{13}$ v Budyšíně založili první lužickosrbskou „učenou“ společnost Maćica Serbska, orientovanou již plně jazykově a etnicky.

V kontextu vývoje teritoria Lužice a její slovanské složky obyvatel na konci 18. a zejména v první polovině 19. století je možno konstatovat, že zásadní změny v čase společenské, politické a ekonomické restrukturalizace Evropy ve sledované době se - pokud jde o Lužické Srby - projevily výrazně ambivalentně:

1) Na jedné straně bezpochyby uspíšily jejich transformaci v novodobé etnikum a umožnily relativně úspěšné „národní obrozeni““, založené zejména na jazykové bázi a inspirované především českým př́ikladem. Bez této dynamické etapy svého národního vývoje by již dnes Lužičtí Srbové zřejmě jako svébytná etnická kolektivita neexistovali.

2) Společenské a ekonomické změny, povinná školní docházka a sílící mobilita obyvatel však současně akcelerovaly i jazykovou a etnickou asimilaci, tj. postupný pokles komunikativního významu lužické srbštiny a následný jazykový posun v řadě oblastí Lužice. Tento proces pokračoval kontinuálně po celé 19. a 20. století až do současnosti, kdy lužickou srbštinou hovoří již méně než 20000 osob. ${ }^{14}$

Období 19. století je považováno za klasickou dobu „národních obrození“ v Evropě. Zatímco mnohá z těchto hnutí (české, finské, litevské aj.) dosáhla výrazných výsledků a na počátku 20. století vyústila dokonce v založení vlastního národního státu, jiná „uvázla na půli cesty“ či byla spíše neúspěšná (Hroch 1986). Teoretik problematiky národních obrození, historik Miroslav Hroch, pokládá právě Lužici za jeden z př́ikladů snah o vytvoření novodobého národa, ve kterých fáze „B“(vlastenecká agitace) nepřerostla - přes dílčí úspěchy -

12 Zmíněný posun směrem ke vnímání etnického faktoru je možno i symbolicky dokumentovat. Kupříkladu již „otec zakladatel“ lužickosrbské žurnalistiky Jan Bohuchwał Dejka (německy Johann Gottlob Deuka/Döke/Doecke) oceňuje v roce 1809 (nekriticky) Napoleona právě za to, že po jím vynuceném územním zmenšení Pruska v rámci Tylžského míru došlo - ovšem pouze dočasně k soustředění velké většiny (cca 95 \%) lužickosrbské populace v jednom státním útvaru - tj. Sasku (Stawizny Serbow 1975, 2. díl: 35-36, 51; Šołta 1990: 117-118). Po změně hranic v roce 1815 žilo naopak cca 80 \% lužickosrbské populace na teritoriu Pruska (Stawizny Serbow 1975, 2. díl: 51). 
ve fázi „¿“(masové národní hnutí) a nevyústila v zastavení asimilačního procesu. Důvodem je podle něho př́lišná disproporce mezi dominantní a minoritní populací, malá početnost etnika a absence lužickosrbského městského centra (Hroch 1986: 54, 65, 280-281). ${ }^{15}$ Přesto je v rámci dalšího vývoje lužickosrbských emancipačních snah možno poukázat na řadu aktivit a úspěchů.

\section{0./21. století: možnosti a limity}

Nejednoznačnou rovinu pocitované jednoty a sounáležitosti Lužických Srbů na celém teritoriu Lužice je nesnadné postihnout. Na rozdíl od majoritních, „státních“ národů, překonávajících v 19. století lokální a regionální roztř́íštěnost působením centralistických vlivů či pomocí školní výuky a mediální produkce v kodifikovaném společném jazyce, ${ }^{16} \mathrm{v}$ lužickosrbském kontextu tyto prvky bud' zcela absentovaly, či byly logicky mnohem slabší. Přes vznik střešní národní organizace Domowina (založena 1912) zůstávala existence společného „lužickosrbského národa“ $v$ duchu andersonovského „myšleného společenství“ až do roku 1945 spíše jen vizí nepočetných kruhů inteligence. V lužickosrbské populaci přetrvávalo mnohočetné divergentní dělení, a to nejen regionální (Horní versus Dolní Lužice, ale v jejich rámci i geografické subregiony jako Slepsko ve střední Lužici či ekonomicky se vydělující hornatá jižní část Horní Lužice), ale založené i na dalších principech. Zcela zásadní bylo dělení konfesní (evangelíci, původně většinoví, avšak ve 20 . století postupně se asimilující, versus katolíci, stále více se prosazující v regionu na severozápad od Budyšína). ${ }^{17}$ Avšak dokonce i v dnešním jádru slovanské Lužice - nevelké (cca $250 \mathrm{~km}^{2}$ ) a nábožensky i etnicky doposud relativně kompaktní „katolické“ oblasti - je dodnes možno vymezit několik (kulturně, dialektálně, společensky, ekonomicky) výrazných mikroregionů („horní vsi“, Delany, Radwor a okolí, kulowská farnost a další).

Zmíněná dominance partikulárních a divergentních jevů v lužickém i lužickosrbském kontextu se poněkud proměnila po roce 1945. Klíčovým momentem se v tomto kontextu stalo přijetí „Zákona o ochraně práv lužickosrbského obyvatelstva“"18 v roce 1948 (Sasko), respektive 1950 (Braniborsko), garantujícího lužickosrbské složce obyvatelstva regionu rovnoprávnost a kulturní

Dolnolužický německý šlechtic, cestovatel a spisovatel, hrabě Hermann von Pückler-Muskau nacházel ve 20. letech 19. století při svém pohledu na postavení Lužických Srbů v Německu řadu podobností se vztahem Irů a Angličanů (Pückler-Muskau: 237; cit. dle Stawizny Serbow, 2. díl: 58-59). Tehdy zřejmě nebyl v řadě momentů daleko od pravdy. Dnes, po téměř 200 letech, se ovšem situace obou Pücklerem komparovaných národů výrazně liší, ačkoli i Lužičtí Srbové se po obou světových válkách (bezúspěšně) pokusili o vytvoření samostatného státu. Modelovým příkladem je kupříkladu Francie.

17 Přesun těžiště lužickosrbských národních aktivit ve prospěch katolíků (v celkovém rámci etnika původně výrazně menšinových) byl dán souběhem několika vlivů. Těmi byly jak společenské prvky (mj. vyšší stupeň konfesně-národního vědomí a s ním spjaté endogamnosti v katolickém regionu; významné byly i přetrvávající vazby k Čechám), tak i ekonomické jevy (sebevědomá selská vrstva). 
autonomii. Po vzniku sítě národních institucí (školství, tisk, rozhlasové vysílání ad.) postupně došlo k sociální konstrukci (společné) lužickosrbské etnické identity a rovněž k jistému sblížení katolické a evangelické složky, respektive Horní a Dolní Lužice na bázi „srbskosti“ jakožto společného jmenovatele. Konvergentní trendy různorodých teritoriálních a konfesních složek lužickosrbské minoritní populace byly však i nadále výrazně slabší nežli v rámci procesů formování většiny státních národů. Motiv (plné) etnické jednoty Lužických Srbů tak v praxi nadále zůstával (a dodnes zůstává) spíše voluntaristickým přáním úzké vrstvy (zejména hornolužickosrbské) inteligence; na oficiální, zejména akademické rovině se ovšem etabloval a prosadil. ${ }^{19}$

Konflikt puristického modelu (vymezujícího národy pomocí etnicko-kulturních kontur) s pluralistickou koncepcí pohledu na etnicitu či jazyk je možno pozorovat i v lužickosrbských (kulturních) dějinách. Zatímco v západoevropském kontextu převládl spíše občanský princip identifikace národa („nation“) se státem, opírá se novodobá středo- a východoevropská národní tradice především o „herderovskou“ koncepci, akcentující společný jazyk a kulturu. Z této koncepce také vyšlo národní obrození 19. století v Lužici, které usilovalo o to definovat a vymezit lužickosrbskou složku zdejší populace jako odlišnou od německé. Využívalo přitom kromě etnicko-jazykového faktoru také rovinu supraetnickou (slovanství versus germánství - tento akcent byl zčásti opětovně posílen po porážce fašistického Německa v roce 1945, kdy byla „slovanská karta“ politicky využívána). Zejména po roce 1949 (vznik NDR) rovněž zesílil diverzifikační význam roviny kulturně-geopolitické - tj. „Západ“ versus „Východ“.

Při úzké kulturní a ekonomické spjatosti a propojenosti lužickosrbské a německé populace (zhruba od počátku 20. století jsou Lužičtí Srbové takřka plně bilingvní) bylo ovšem ostré vymezení „lužickosrbského“ a „německého“ fenoménu mnohdy spíše abstraktem nežli každodenní realitou. Přesto však měl tento trend i své nezanedbatelné výsledky. Ačkoli v Lužici nevedl ke vzniku „národního“ státu (tak jako tomu bylo kupříkladu po roce 1918 v případě Československa, Finska či pobaltských zemí), došlo u určité části (zejména katolických) Lužických Srbů bezpochyby k vytvoření novodobého „etnického vědomí“. Forma a intenzita tohoto vědomí byly ovšem výrazně flexibilní: kolísaly a variovaly v různých časových obdobích, teritoriálně i jinak. Hranice identifikace se „srbstvím“ (stejně jako aktivního užívání lužické srbštiny) mohla procházet napříč i rodinami či se proměňovat v průběhu osobního vývoje jednotlivce. Etnická identita není ničím stabilním. Praxe ukazuje, že „míra etnicity stoupá, klesá a mění se v reakci na významné vnější jevy a celkový vývoj. Stejně jako mnohé jiné aspekty kultury nesleduje př́mou linii“ (Fishman 1985: 517).

Pokud jde o shrnutí historie vývoje intenzity a projevů etnické identity Lužických Srbů v delším časovém horizontu, pohybujeme se na dosti nejisté

19 Zajímavým dokladem "sbližovacích snah“ je v daném kontextu výměna "otevřených dopisư” mezi (mladými) Hornolužickými a Dolnolužickými Srby, publikovaná v kulturním časopise Rozhlad v ročníku 66 (2016). 
půdě. Exaktní srovnání kupř́íkladu současného stavu se situací ve druhé polovině 19. století je - vzhledem $k$ tehdejší indiferentnosti etnického vědomí velké části obyvatelstva Lužice - krajně obtížné či prakticky nemožné.

Za období posledních 150 let sice existuje nemalé množství relevantních dat a informací o etnickém fenoménu na teritoriu Lužice ${ }^{20}$ - otázkou však zůstává, do jaké míry je možno je zevšeobecnit a také nakolik je lze interpretovat v intencích současných diskurzů o „etnické identitě“. Ani „národní“ postoje mnohých vůdčích lužickosrbských osobností 19. a první poloviny 20 . století nebyly vždy jednoznačné; ${ }^{21}$ „lid“ zůstával z velké části etnicky nevyhraněn. Prakticky v celé Lužici se zhruba až do začátku 20. století tradičně hovořilo převážně lužickosrbsky, živoucí byly i mnohé (sub)regionální jevy materiální a duchovní kultury. Z čistě jazykové a kulturní roviny však nelze automaticky odvozovat existenci etnického vědomí - mezigenerační předávání jazyka a kulturních fenoménů u Lužických Srbů bylo (a v současnosti mnohdy i je) z velké části spíše aktem tradice a setrvačnosti než uvědomělým (etnickým) projevem. Proto také lužickosrbský jazyk a další kulturní prvky, nepodpořené volním aspektem, vykázaly jen slabou rezistenci vůči jazykovému přechodu od lužické srbštiny k němčině, který proběhl ve většině oblastí Lužice (zejména v evangelických regionech) po roce 1945.

Přesto však je právě období zhruba prvního desetiletí po druhé světové válce zřejmě možno označit jako dobu snad nejvýraznější novodobé cézury mezi lužickosrbským a německým živlem v Lužici. Poválečná, historicky první početnější generace lužickosrbské a slovansky orientované inteligence, absolvující speciálně zřízená gymnázia v severních Čechách, ${ }^{22}$ by snad za jiných, příhodnějších politických a společenských podmínek měla šanci stát se nositelem procesu dotváření se Lužických Srbů jako relativně plně konsolidovaného národa. Avšak ani pro toto období, ani pro region s nejvyšší mírou lužickosrbského etnického vědomí - tj. „katolickou“ oblast mezi městy Budyšín a Kamjenc (něm. Kamenz) s cca 10000 obyvateli $^{23}$ - a ani pro etnicky nejvyhraněnější vrstvu (inteligenci) nejspíše není možné aktivní vymezení se Lužických Srbů přeceňovat. Následující hodnocení, týkající se jazykové politiky, můžeme vztáhnout i na další roviny národního života v Lužici: „Velká část Lužických Srbů, zejména vně oblasti katolických lužickosrbských farností,

Vysoce ceněno a využíváno je zejména důkladné sčítání Arnošta (Ernsta) Muky z první poloviny 80. let 19. století, evidující 166000 Lužických Srbů (Muka 1884-1886).

21 Kupříkladu lužickosrbští evangeličtí faráři si brali německé manželky, nebot mezi ženami stejné národnosti pro ně stěží bylo možno nalézt společensky odpovídající partnerku.

22 Jednalo se o několik stovek mladých Lužických Srbů - při formování jejich etnického vědomí měl mimořádně velký význam fakt studia a dospívání na poválečných lužickosrbských gymnáziích v Československu - zejména ve Varnsdorfu, dále i v České Lípě a v Liberci (Krawc 2005).

23 Na rozdíl od jiných oblastí Lužice se zde i po reformaci v 16 . století jako dominantní udrželo (i dnes živoucí a vlivné) katolické náboženství, v praxi multiplikující vliv etnické hranice Lužický Srb versus Němec o religiózní rovinu. Také v lužickém rámci zcela nadstandardní novodobé vztahy této oblasti k Čechám souvisejí s náboženskou denominací. Pouze zde plní doposud lužická srbština do značné míry základní komunikativní funkci; je i vyučovacím jazykem části zdejších škol. 
přijala ... státní opatření spíše pasivně. Často je užívala, aniž by je považovala za cenné vymoženosti.“ (Ela 1998: 87) Od konce 50. let - kdy došlo k politickému znemožnění snah o realizaci nejen pouze formální koncepce „Lužice bude dvojjazyčná!“ve prospěch hesla „Lužice bude socialistická!“ (Meškank Zahrodnik 2011: 76-102) - se pak dělicí čára mezi „lužickosrbským“ a „německým“ stává mnohdy ještě méně zřetelnou.

V souvislosti s diskreditací „národní“ myšlenky v éře fašismu a následnou politikou „internacionalismu“ vyrůstaly poválečné generace NDR v ovzduší jen málo zdůrazňujícím národní/etnický aspekt. Lužickosrbské instituce a kulturní specifika byly sice oficiálně podporovány - počet uživatelů jazyka však nadále klesal. Ne zcela jednoznačná byla i pozice Lužických Srbů v rámci oficiální doktríny, spíše se vyhýbající jejich jednoznačnému definování jakožto alternativy: tedy osobitého, neněmeckého etnika sídlícího v NDR. Samotné slovo „národ“ (narod; Nation) bylo v souvislosti s Lužickými Srby oficiálně sotvakdy užíváno - spíše bylo suplováno pojmy „národnostní menšina“ (narodna mjeńšina; nationale Minderheit) či „obyvatelstvo/lid“ (lud, ludnosć; Volk). V tomto hlavním proudu však nalezneme i dílčí protiproudy: kupříkladu prosazení se bromlejovské školy „etnických procesů“ ${ }^{424} \mathrm{v}$ SSSR umožnilo od 70. let ideologicky zaštitovat snahy o podporu lužickosrbského etnického vědomí a také lužické srbštiny jako jeho složky.

Po roce 1990 sice docházelo u části německé populace ke xenofobním náladám a projevům, až na výjimky však nebyly výrazněji směrovány proti Lužickým Srbům. Skutečnost, že se jedná o autochtony s dlouhodobou tradicí života v regionu, vytváří - stejně jako fakt jejich německého státního občanství, loajality a kulturní blízkosti - určité „mimikry“. Kupříkladu v porovnání se Sámy či dalšími evropskými minoritními etniky Lužičtí Srbové prakticky nezdůrazňují fenomén své autochtonnosti a politicky jím neargumentují. Velká část Němců (dokonce včetně některých oficiálních představitelů) tak lužickosrbskou populaci vnímá spíše jako osobitou regionální/folklorní skupinu, nežli jako svébytný národ. Zdá se také, že podstatná část Lužických Srbů tento stav vcelku akceptuje a že od roku 1990 mezi nimi dále sílí trend posouvající sebeidentifikaci spíše ke kulturnímu pluralismu a západoevropskému, tj. občanskému pojetí „národa“. Skutečnost, že po znovusjednocení Německa se Lužičtí Srbové stali občany mnohem většího, bohatšího a světu otevřeného demokratického státu, tento trend ještě umocňuje. Nikoli náhodou tak zpívá současná mladá hornolužická folková písničkářka Lydija Jaworkec o tom, že Lužičtí Srbové „mají kořeny v Lužici, ale větve ve světě“25 (ovšem zmiňovaným „světem“ je v praxi především Německo).

V Lužici je tak dnes možno sledovat splývání a prolínání lužickosrbské (etnické) identity s německou prakticky ve všech rovinách. Hranice/kontura

24 Viz blíže v následujícím oddílu textu.

25 V písni Hłuboke dohlady in: Jaworkec 2010. 
mezi „lužickosrbským“ a „německým“ není mnohdy nijak ostrá a zřetelná - již i tak tradičně spíše málo výrazné lužickosrbské etnické vědomí se dále drolí a láme do vědomí podvojného, lužickosrbsko-německého. V dané souvislosti je však třeba pozorně diferencovat. Zatímco v „katolickém“ jádru srbské Lužice je možno dosud nalézt řadu etnicky plně vědomých Lužických Srbů, postoupila etnicko-jazyková asimilace v „evangelických“ oblastech Horní Lužice a v celé Dolní Lužici již mnohem dále.

Se zmíněnými skutečnostmi souvisí také nejednoznačnost a prolínání pojmů „národni““ (narodny; National-) a „státní“ (statny; Staats-) v oficiálních úř̌edních dokumentech - oba tyto pojmy mohou být použity k označení „příslušnosti ke státu“. Mnozí Lužičtí Srbové se tak současně cítí být „Němci“ (i když mnohdy je obtížné odlišit občanskou, etnickou či kulturní složku této roviny) i „Srby“. Důležitou roli hraje u mnoha Lužických Srbů i snaha nebýt ,jiný“, „nápadný“, „nevymykat se“ a necítit se v důsledku toho „vyloučen“; u mládeže je pak mimořádně významná i potřeba odpovídat trendu být „,cool“. ${ }^{26}$ Sám fakt existence „podvojné identity“ je tak v Lužici v praxi (až na výjimky) přijímán a chápán jako přirozený.

\section{Mezi primordialismem a (post)modernismem}

Ačkoliv již v roce 1882 pronesl francouzský historik Ernest Renan často citovanou definici, podle níž „,existence národa je ... každodenní plebiscit“, ${ }^{27}$ dominovalo při konstituování novodobých národů nejen v 19. století, ale i hluboko do 20. století primordialistické (esencialistické, objektivistické) pojetí národa a etnicity, považující tyto fenomény za „odvěké“, askribované kulturní jevy, jež lze chápat jako posvátné a podřídit jim jiné hodnoty. Etnicita je nahlížena jako klíčový jev kolektivní identity, nadřazený jiným, „neetnicky“ konstruovaným společenským vzorcům či situačním identitám.

Teprve ve druhé polovině 20. století začal být uvedený koncept postupně nahrazován pojetím konstruktivistickým (modernistickým, subjektivistickým). Podle něj vznikla současná forma etnického vědomí teprve relativně nedávno (před zhruba dvěma sty lety) v souvislosti s řadou kulturních, sociálních a ekonomických činitelů a změn. Tuto „opci společenského organizování se“ je tak možno nahlížet coby imaginární, abstraktní a relativní společenský konstrukt.

I když v současnosti konstruktivistické náhledy a paradigmata ve společenskovědní sféře jednoznačně dominují, neznamená to, že primordialistické vnímání etnicity a etnických jevů vymizelo. Právě naopak: toto pojetí vykazuje silné setrvačné aspekty a rezidua, projevující se jak v běžné každodenní praxi emocionálního pouta etnických loajalit (banal nationalism; Billig 1995), tak i ve vypjatých

Šatava 2009: 100-101; Šatava 2005: 29, 216-217. K etnické identitě

a jazykovým postojům lužickosrbské mládeže viz Šatava 2006a.

27 V závěru úvahy Co je to národ? (Qu'est-ce qu'une nation?), přednesené na pařížské Sorbonně 11. března 1882; česky kupř. Renan 2003. 
chvílích historických a politických změn. Je to mnohdy právě tato (jen zdánlivě překonaná) emocionální rovina, ${ }^{28}$ jež přenáší etnické pospolitosti staletími.

Tradiční koncepce. Zatímco v západní Evropě dominoval v rámci novodobého pojetí „národa“ (resp. „nacionalismu“) především státní (resp. občanský) princip, prosadila se ve východní Evropě vzhledem k odlišným politickým podmínkám představa „národa“, opírající se (v herderovském duchu) o společný jazyk, kulturní znaky a národní „mravy“ (Volksgeist). Také snahy lužickosrbského národního obrození v 19. století vyšly z jazykově-kulturního modelu národa. Při vymezení se vůči německému elementu se - stejně jako v prrípadě českého obrození, jež bylo pro Lužické Srby důležitým vzorem paradoxně jednalo o nápodobu německých národních snah.

V souladu s dobovými paradigmaty šlo o takřka bezvýhradně primordialistické pojetí existence „lužickosrbského národa“. Na rozdíl od praxe velkých, „státních“ národů se však minoritní etnikum muselo v rámci sebereflexe výrazněji vyrovnávat s některými slabinami objektivisticky koncipované teorie, vyplývajícími z její rigidnosti a statičnosti. To se týkalo kupříkladu nesamozřejmosti jazykové a etnické mezigenerační štafety u menšinových populací ${ }^{29}$ či problematiky smíšených manželství a identity jejich potomků.

Přesto je možno konstatovat, že primordialistický přístup k lužickosrbské etnicitě dominoval téměř po celé 20 . století. V meziválečném období byl ovšem tento fenomén odborně jen málo reflektován; spíše se jednalo o setrvačné prodloužení linie 19. století v duchu předpokládané generační návaznosti na poli jazyka a národního vědomí.

Období NDR lze rozdělit na dvě fáze:

1) V první, zahrnující zhruba 50.-70. léta, nebyla společenskovědní situace v zemi nakloněna studiu národa a národních specifik - témat zkompromitovaných nacistickou ideologií a politicky ožehavých i v rámci tezí marxismu-leninismu. Přesto se však i v této době objevily zajímavé pokusy o dokumentaci, analýzu a interpretaci jazykové a etnické situace Lužických Srbů - jmenujme například výzkum Institutu lužickosrbského národopisu (Institut za serbski ludospyt) v obci Radwor (něm. Radibor) v letech 1963-1964, jenž ve své době tematicky i metodologicky „předběhl dobu“ (Nowotny 1965; Musiat 1967). ${ }^{30}$

2) Vznik a nástup „teorie etnosu“, respektive „školy etnických procesů“ v 70. letech 20. století, zaštítěných jménem sovětského etnografa Juliana V. Bromleje, jehož stěžejní text Etnos a etnografie byl přeložen i do němčiny (Bromlej 1977), umožnil do té doby ideologicky nemyslitelný nástup etnických studií i v satelitních státech SSSR. ${ }^{31}$ Také v Lužici bylo náhle možno zkoumat

28 V intencích pojetí etických vazeb a etnického cítění („sentiments“) v textech Clifforda Geertze.

29 Viz próza předního lužickosrbského patriota a literáta Jakuba Barta-Ćišinskeho „Narodowc a wotrodźenc” (Vlastenec a odrodilec) z roku 1879.

31 To se týká i Československa, kde však klíčová Bromlejova práce vyšla pouze ve slovenštině (Bromlej 1980). 
problematiku etnické identity, asimilace či jazykové situace (kupř. Kasper 1981; Nedo 1982). Přes pozitivní praktický vliv zmíněné skutečnosti je však třeba říci, že Bromlejovy teze jen v malé míře překračovaly subjektivistické dědictví Stalinovy „teorie národa“, jejímž - opět bezpochyby primordialistickým - prodloužením byly (Horálek 2012: 32). Uvedený přístup k fenoménu národa a etnicity tak přetrval až do konce existence NDR či ještě déle.

Změny po roce 1990. Nové př́stupy a paradigmata se v kontextu etnojazykové situace Lužice rodí a jsou využívány teprve v uplynulých dvou dekádách. Jedná se o několik navzájem provázaných vlivů a činitelů:

1) Po pádu železné opony, otevření se světu a znovusjednocení Německa pronikají i do lužickosrbských společenskovědních kontextů prizmata konstruktivistických přístupů k etnicitě. V každodenní praxi však nejsou příliš zdůrazňována a zůstávají spíše omezena na úzkou vrstvu odborníků.

2) V kontextu nových právních úprav, definujících práva Lužických Srbů v Sasku (resp. Braniborsku), je příslušnost k lužickosrbské národnosti ponechána zcela na vůli příslušné osoby a nemusí být nijak konkretizována či dokazována. Podle § 1 Saského lužickosrbského zákona z roku 1999: „K lužickosrbskému národu patří ten, kdo se k němu hlásí. Toto přihlášení se je svobodné. Nesmí být ani odpíráno, ani přezkoumáváno. Z tohoto přihlášení se nesmějí být vyvozena žádná znevýhodnění.“32

Zmíněný volní přístup tak do jisté míry nepřímo (přinejmenším statisticky) kompenzuje reálné vlivy asimilačního procesu: pokud lze být Lužickým Srbem jen na základě přihlášení se k této skutečnosti (tj. i bez objektivních skutečností, jako je znalost jazyka či existence rodinných tradic), je teoreticky snad stále možno mluvit o často uváděném počtu 40000 příslušníků tohoto etnika. ${ }^{33}$ Pokud jde o jazykovou, respektive školskou stránku - i když nedávný přechod z předchozího modelu jazykově definovaných tříd (A a B) ${ }^{34}$ ke koncepci bilingvní imerzní výchovy (koncept 2plus) byl mimo jiné vyvolán zejména nedostatkem žáků z (jazykově) lužickosrbských rodin, je i tuto změnu možno chápat jako symbolické rozvolnění ostré etnické/jazykové hranice.

3) Dalším významným činitelem se stal celkový modernistický kontext „menšinových“ (tj. nejen etnických) práv, řadící úsilí o přetrvání minoritních etnik, jejich jazyků a kultur do mnohem širší, univerzální matrice. V praxi etnojazykových (mnohdy revitalizačně a antiglobalizačně zaměřených) aktivit se tato skutečnost mimo jiné projevila znatelným posunem od etnické roviny k rovině jazykové (v kontextu Lužice tedy konkrétně posunem od „podpory

V německém originálu: „Zum sorbischen Volk gehört, wer sich zu ihm bekennt. Das Bekenntnis ist frei. Es darf weder bestritten noch nachgeprüft werden. Aus diesem Bekenntnis dürfen keine Nachteile erwachsen." (Gesetz über die Rechte... 1999: § 1 Sorbische Volkszugehörigkeit)

34 V „A-třídách" byla lužická srbština převažujícím vyučovacím jazykem, v „B-třídách“ se učila pouze jako předmět. Tato koncepce byla po roce 2000 postupně nahrazena dvojjazyčným konceptem 2plus (Smolina 2007). 
Lužických Srbů“ k „podpoře lužické srbštiny“). ${ }^{35}$ Také uvedená tendence svědčí o ústupu snah o jednoznačné vymezení lužickosrbské etnicity a o „postmoderním" rozostření tohoto fenoménu.

Současná situace. V uplynulém čtvrtstoletí se tak v teorii i praxi lužickosrbských národních snah poměrně komplikovaně prolínají jak primordialistické, tak i konstruktivistické př́ístupy a prvky. Oficiální pozice však nebyla definována či analyzována, a to ani ze strany představitelů Lužických Srbů (Domowina; Nadace pro lužickosrbský národ), ani pokud jde o vědecká pracoviště (Lužickosrbský institut, Budyšín; Institut pro sorabistiku, Univerzita Lipsko).

1) Etnicita: na poli etnicity se tak v Lužici vychází ze zmíněného principu „svobodného přihlášení se k národnosti“. Tento (zdánlivě vysoce liberální a demokratický) model, dávající možnost volby či chceme-li individuálního renanovského plebiscitu, má však i svá nemalá úskalí a problémy. Etnickou sebeidentifikaci není reálně možno měnit ze dne na den. Právo na „svobodnou volbu etnické příslušnosti“ sice něco takového zdánlivě umožňuje, praxe je však jiná. Američtí sociologové E. a V. Hughesovi v této souvislosti napsali: „Pokud je snadné zříci se příslušnosti ke skupině, není to opravdová etnická skupina.“ (Hughes - Hughes 1952: 156; cit. dle Marger 1994: 16) ${ }^{36}$

V Lužici navíc k této problematice přistupuje další komplikující faktor: značná (situacionistická) propustnost etnojazykových hranic a rovina podvojné lužickosrbsko-německé identity. U řady osob nelze stanovit ostrou dělicí linii mezi „lužickosrbským“ a „německým“. Přitom podvojná identita může být jak vyvážená, tak naopak výrazně vychýlená ve prospěch jedné z identit. Míra etnicity může také kolísat v čase, stejně jako oscilovat mezi vypjatým nacionalismem a příležitostnou „Sunday ethnicity“ (Novak 1971: 37; cit. dle Dubovický 1998: 25).

Pokud jde o censy a další početní údaje, jen malá část evropských státních útvarů v současnosti sčítá a registruje údaje týkající se deklarované etnické příslušnosti. Absence takovýchto oficiálních statistik platí i v případě dnešního Německa (Ela 2010) - tím se zdejší situace liší od nástupnických států bývalého RakouskoUherska a dalších zemí východní Evropy. Skutečnost, že etnická příslušnost není v Německu úředně doložitelná, bývá také uváděna jako jedna z překážek vzniku hypotetického lužickosrbského voleného menšinového zastupitelského orgánu (Serbski sejm $)^{37} \mathrm{v}$ kontextu potíží s registrací osob majících volební právo. Jistě, proces dokazování „srbstvi“ by byl mimořádně komplikovaný a u mnohých (i „národně uvědomělých") Lužických Srbů by se zřejmě setkal také s odporem. Pro srovnání je však třeba připomenout, že kupříkladu norští Sámové se takového řešení nezalekli a pro potřeby registrace voličů do Sámského parlamentu vytyčili (jakkoli vágní a zpochybnitelná) kritéria původu, tj. „sámskosti“.

2) Jazyk: na rozdíl od některých jiných bilingvních/diglosických oblastí Evropy (Wales, Skotsko, Finsko aj.) není v Lužici registrován ani - v porovnání

35 Mj. v kontextu snah o jazykovou revitalizaci (Nowak 2013).

36 "If it is easy to resign from the group, it is not truly an ethnic group."

37 Viz www.serbski-sejm.de či tištěný informační leták (Serbski sejm s.d.). 
s etnicitou zdánlivě „změřitelnějši“ - počet uživatelů menšinového jazyka. Přitom právě lužická srbština je bezpochyby hlavním etnodiferencujícím znakem, odlišujícím Lužické Srby od Němců. Přes spíše akademická či voluntaristická tvrzení, že „plnohodnotným“ Lužickým Srbem je možno být i bez znalosti řeči, bývá často právě schopnost hovořit lužickosrbsky vnímána a prezentována jako sine qua non lužickosrbské etnicity. Skutečnost, že vedle jazyka existuje v praxi jen málo jiných znaků vymezujících Lužické Srby jako svébytné etnikum, zastáncům názoru o roli jazyka jakožto „etnické“ komponenty či etnodiferencujícího znaku nahrává (Ela 2014: 103-104).

Shrnutí. Jak tedy v lužickosrbském kontextu nahlížet na tradiční soupeření dvou zmíněných ambivalentních teorií etnicity? Dávný spor primordialistické a konstruktivistické koncepce není v Lužici ani zdaleka dořešen; oba přístupy se v teorii a praxi prolínají (nejčastěji podle momentálních ideových, pragmatických aj. kontextů a potřeb). Je rovněž namístě si připomenout, že rozpory mezi oběma krajními pojetími etnicity mohou být menší, nežli se zdá. Rozdíly mezi těmito paradigmaty jsou totiž mnohdy dány spíše rozdílnou akcentací shodných klíčových momentů, souvislostí a vztahů (Hroch 2009: 43 n.).

Od svých slovanských sousedů se Lužičtí Srbové liší mnohem větší mírou etnické hybridity či dvojí identity (Tschernokoshewa 2013); tato skutečnost se (v některých situacích) projevuje i výraznější ochotou k akceptaci státního/občanského pojetí národa.

Oproti praxi před rokem 1990 také zřetelně zesílilo prizma nahlížející na Lužické Srby a lužickou srbštinu jako na součást „kulturního dědictví lidstva“. ${ }^{38}$ Zmíněný přístup se poté prolíná s aktuální tematikou antiglobalizačních snah, multikulturalismu, biodiverzity a ekologie. Dřívější pohled, zaměřený striktně pouze na menšinová a jazyková práva, byl tedy v nedávné minulosti nejen podstatně rozšířen, ale dosahuje i nové, postmoderně zabarvené kvalitativní roviny. Snaha o odpověd’ na výše zmíněnou a na konkrétní jedince zaměřenou otázku, kdo je Lužický Srb, tak do značné míry ustupuje do pozadí či přímo pozbývá významu: podstatné je naopak „správné“ akcentování kolektivní lužickosrbské a menšinové tematiky v rámci aktuálních společenských témat a za použití adekvátního „newspeaku“.

Nakolik jsou zmíněné změny pro Lužické Srby a jejich přetrvání jako svébytné entity prospěšné, je obtížné říci. Každá epocha má své (i když mnohdy pouze formální) společenské a kulturní vzorce, preference a dobově podmíněné tematizace. Ještě před několika málo dekádami nepředstavitelná společenská akcentace a pozitivní konotace pojmu „menšina“ může být jistě malým etnickým skupinám (a tedy i Lužickým Srbům) ku prospěchu.

Jakkoli je jistě užitečné využívat příhodných společenských kontextů, je však přesto třeba nespoléhat jen na ně; vedle „velkých témat“ (v duchu tönnie-sovského Gesellschaft) je žádoucí i nadále rozvíjet také nosné, ryze 
komunitní kontexty (Gemeinschaft). Tradiční pojetí „národa“ je totiž současnou postmoderní optikou vytlačováno a nahrazováno někdy až příliš abstraktními rovinami „menšinových/lidských práv“, multikulturalismu a diverzity, v nichž se vlastní předmět zájmu může paradoxně ztrácet či být vnímán jako anachronismus. I pro Lužické Srby jsou tak vysoce aktuální slova Clauda Lévi-Strausse: „Každá kultura se rozvíjí díky vzájemným výměnám s jinými kulturami. Musí však klást určitý odpor, jinak by záhy neměla nic specifického, co by mohla směňovat." (Yacoub 1996: 3) Na tom, zda lužickosrbské etnikum bude schopno nalézt vyváženou pozici mezi zřetelným sebevymezením a otevřením se jiným vlivům tak bude záviset nejen akademická disputace mezi primordialismem a konstruktivismem, ale budoucnost Lužických Srbů a jejich jazyka vůbec.

\section{Dodatek: lužickosrbské elementy jako společný jmenovatel lužického regionalismu}

Roviny teritoriální a etnické identity prošly v Lužici v novověku složitým vývojem. Středověký zemský regionalismus začal být od 17. století postupně doplňován či nahrazován také saskou, respektive pruskou identitou. Po roce 1800 se navíc i zde stejně jako jinde v Evropě vytváří a prosazuje novodobé pojetí národa; vedle pozvolna sílícího národního vědomí a obrozeneckých snah Lužických Srbů je třeba připomenout i postupně se rodící stř̌ešní „celoněmeckou identitu“, kulminující po vzniku Německa v roce 1871. Ani ta ovšem nevytlačila identity „saskou“ a „pruskou“ jako komponenty nižšího řádu, působící na pomezí regionálního a subetnického vědomí. V 19. století začíná být terén Lužice také zřetelněji nahlížen etnickou optikou jako dichotomický region dvou populací - dominantních (již nejen společensky, ale postupně i početně) Němců a asimilujících se Lužických Srbů.

Také po politickém rozdělení lužického regionu mezi Sasko a Prusko nadále souběžně přetrvávalo rovněž tradiční dělení na Dolní a Horní Lužici, jejichž historické vymezení se ovšem plně nekrylo se sasko-pruskou hranicí (jež se navíc v kontextu politických dějů i proměňovala). Až do roku 1815 převládalo vnímání Horní a Dolní Lužice jako dvou samostatných celků. Dnes běžně užívané střešní pojmenování obou zmíněných zemí jako Lužice je pro předchozí období vlastně nesprávné (Stawizny Serbow 1975, 2. díl: 51). V rámci vazeb Horní a Dolní Lužice bylo dlouho jen málo styčných bodů. V průběhu 19. století lze již sice zaznamenat určité „dvojjediné“, tj. celolužické povědomí, jeho vymezení je ovšem spíše symbolické a vágní. Určitým společným jmenovatelem se však postupně stala přítomnost slovanského obyvatelstva $\mathrm{v}$ obou částech Lužice. $V$ dané souvislosti je možno vyslovit hypotézu, že vzhledem $k$ historickému zemskému a politickému dělení, respektive změnám vnitřní hranice lužického teritoria, se Lužice stala společně chápaným kulturním a teritoriálním celkem do značné míry 
zejména díky existenci lužickosrbského elementu. To platí až do současnosti: není zřejmě náhodou, že zejména z kruhů lužickosrbské inteligence vyšel (zatím?) poslední pokus o teritoriálně-administrativní spojení obou Lužic míněny jsou neúspěšné snahy o ustavení samostatné spolkové země Lužice po politickém znovusjednocení Německa v roce 1990.

Lužická a lužickosrbská (tj. regionální a etnická) identita mají k sobě v současnosti blíže, než by se na první pohled zdálo. Tato skutečnost výrazně souvisí zejména se stále klesajícím počtem osob znalých lužické srbštiny a výrazným posunem některých lužickosrbských kulturních a folklorních jevů a obyčejů (zpěv, malování kraslic, tradiční lidové zvykosloví aj.) do pozice symbolu či atributu „lužičanství“ či Lužice (jazykově při použití němčiny). I když se kupříkladu existence „lužických“ spisovatelů, tj. německých literátů působících v regionu a využívajících ve svém díle kulturní specifika a místní reálie (zejména Erwin Strittmatter), nestala takovým kulturně-regionalistickým symbolem, jakým jsou např́ílad anglicky píšící „velští“ autoři nebo ve španělštině tvořící literáti z Baskicka, je i tento trend možno zaznamenat. Být Lužickým Srbem - respektive v posunuté podobě „Lužičanem“ - je tedy v současnosti pro mnohé možné na bázi regionální kulturní tradice, tedy i bez znalosti lužickosrbského jazyka. I když je v Lužici aktivní řada lokálních (jazykově německých) vlastivědných spolků (Heimatverein), jsou hlavním svorníkem a společným jmenovatelem koncipování celolužického regionálního fenoménu zejména (původně) lužickosrbské elementy.

\section{Závěrem}

Základy novodobé etnicity Lužických Srbů byly položeny v kontextu změn společenského klimatu na přelomu 18. a 19. století; během dalších dvou století pak uvedený fenomén prošel - zejména v souvislosti s politickým vývojem - řadou rovin a fází. Jeho aktuální etapu lze sledovat od roku 1990.

Ani po více než dvou stoletích od počátků novodobého etnického formování a sebevymezení Lužických Srbů není řada otázek spjatých s tímto procesem jednoznačně definována a dořešena. Vzhledem k ne zcela zřejmé (respektive k podvojné) rovině etnické příslušnosti u řady osob, tendenci situačních identit či souběžnému ambivalentnímu působení asimilačních a revitalizačních trendů zůstává současná Lužice etnicky ne plně konsolidovaným a přehledným regionem. Ten je však současně z etnologického a sociolingvistického hlediska pozoruhodným terénem, v němž lze dokumentovat a komparovat řadu obecně platných jevů etnické a jazykové problematiky.

Lužickosrbská „case study“ představuje také osobitý příklad na poli studia národních obrození. Etnická emancipace sice nebyla v Lužici tak úspěšná jako u řady jiných, početně, teritoriálně či ekonomicky silnějších etnik; současně však lze uvést řadu - vzhledem k limitované základně a možnostem až nečekaně výrazných - počinů na tomto poli. Skutečnost, že na teritoriu Lužice 
doposud přetrvává osobitá etnická identita a lužickosrbský jazyk, hovoří sama za sebe a stále nechává otevřené dveře do budoucnosti.

\section{Srpen 2016}

\section{Literatura}

Billig, Michael. 1995. Banal Nationalism. London: Sage Publications.

Bromlej, Julian V. 1977. Ethnos und Ethnographie. Berlin: Akademie-Verlag. Bromlej, Julian V. 1980. Etnos a etnografia. Bratislava: Veda.

Dolowy-Rybińska, Nicole. 2011. Języki i kultury mnieszościowe w Europie: Bretończyci, Łużyczanie, Kaszubi. Warszawa: Wydawnictwa UniwersytetuWarszawskiego: 221-364.

Dubovický, Ivan. 1998. Symbol on the Boundary of Ethnic Groups. In: Pargač, Jan (ed.): Cultural Symbols and Ethnic Consciousness. Prague: Institute of Ethnology, Charles University: 16-32.

Duličenko, Aleksandr D. 1981. Slavjanskije literaturnyje mikrojazyki. Voprosy formirovanija i razvitija. Tallin: Valgus.

Ela, Ludwig. 1998. Serbska rěč w měnjenju łužiskich wobydlerjow. In: Faska, H. (ed.): Serbšćina. Opole: Uniwersytet Opolski - Instytut Filologii Polskiej: 87-88.

Ela, Ludwig. 2010. Kelko je Serbow? Abo - dyrbja so mjeńšiny poprawom ličić? Rozhlad 60: 5: 17-19; 6: 16-18.

Ela, Ludwig. 2014. Sprachenpolitik in der Lausitz. Sprachenpolitik und Sprachenrecht im deutsch-sorbischen Gebiet 1990 bis 2014. Bautzen: Sorbisches Institut/Serbski institut. Fishman, Joshua A. 1985. The Rise and Fall of the Ethnic Revival. Perspectives on Language and Ethnicity. Berlin - New York - Amsterdam: Mouton: 517.

Gesetz über die Rechte der Sorben im Freistaat Sachsen (Sächsisches Sorbengesetz SächsSorbG). Vom 31. März 1999.

Horálek, Adam. 2012. Tři př́stupy k pupkům národů. Primordialistickomodernistický diskurz prizmatem aktivity a objektivity etnicity. Český lid 99: 23-43.
Hroch, Miroslav. 1986. Evropská národní hnutív 19. století. Praha: Svoboda.

Hroch, Miroslav. 2009. Národy nejsou dílem náhody. Praha: Sociologické nakladatelství.

Hughes, Everett C. - Hughes, Helen M. 1952. Where Peoples Meet. Ratial and Ethnic Frontiers. Glencoe (Ill.): Free Press. Jaworkec, Lydija. 2010. CD Lydija "Božemje". Kasper, Měrćin. 1981. Etniska zhromadnosć - rěč - etniske sebjewědomje. Rozhlad 31: 6: 224-230.

Keller, Ines. 1993. Ethnosoziologisches Material über Radiborer Familien 1964. Lětopis 40: 1: 133-141.

Krawc, Mikławš. 2005. Kelko Serbow je po 1945 w sewjernej Čěskej wuknyło? Serbska šula 58: 2: 44-46.

Marger, Martin N. 1994. Race and Ethnic Relations. American and Global Perspectives. Belmont (Cal.): Wadsworth Publishing Company.

Meškank, Timo - Zahrodnik, Ludwig. 2011. Serbske stawizny 2. Wot kónca prěnjeje swětoweje wójny hač do pritomnosće. Budyšin: Ludowe nakładnistwo Domowina.

Muka, Arnošt. 1884-1886. Statistika łužiskich Serbow. Wobličenje a wopisanje hornjo- a delnjo-łužiskeho Serbowstwa w lětach 1880-1885. Budyšin: nákladem spisovatele.

Musiat, Zygmunt. 1967. Ludowědnosociologiske slědźenja w Radworju. Nowa doba 21: 76 (01.04.1967): Předźenak: 4.

Nedo, Pawoł. 1982. Mały lud a jeho kultura. Rozhlad 32: 3: 86-90; 4: 141-146.

Novak, Michael. 1971. The Rise of Unmeltable Ethnics. New York: Macmillan.

Nowak, Měto. 2013. K trěbnosći rewitalizaciskeje koncepcije za dolnoserbsku rěc. Rozhlad 63: 12: 5-9. 
Nowotny, Pawoł. 1965. Někotre wunoški sociologiskich slědźenjow w Radworju. Nowa doba 19: 284 (04.12.1965), zvláštní příloha: 6-8.

Pjech, Edmund. 2014. Kontrowersy wo zažnych stawiznach Serbow. Rozhlad 64: 6: 7-15.

Pollack, Friedrich. 2012. Die Entdeckung der Fremden. Wahrnehmung und Darstellung der Lausitzer Sorben im gelehrten Schrifttum des 17. und 18. Jahrhunderts. Bautzen/Budyšin: Sorbisches Institut/Serbski institut.

Pückler-Muskau, Hermann, von. 1969. Reisebriefe aus Irland. Berlin: Verlag Rütten \& Loening.

Renan, Ernest. 2003. Co je to národ? In: Hroch, Miroslav: Pohledy na národ a nacionalismus. Čítanka textů. Praha: Sociologické nakladatelství: 24-35.

Serbski sejm. s.d. (2015 ?). Informační leták; s.l.: Iniciatiwa Serbski sejm.

Smolina, Manuela. 2007. K prašenjam nastupajo 2plus-projekt.

Serbska šula 60: 2: 52-54.

Stawizny Serbow (Brankačk, Jan Mětšk, Frido). 1. díl. 1975. Budyšin: Ludowe nakładnistwo Domowina.

Stawizny Serbow (Šołta, Jan - Zwahr, Hartmut). 2. díl. 1975. Budyšin: Ludowe nakładnistwo Domowina.

Šatava, Leoš. 1992. K problematice atributů etnické identity a územní př́slušnosti. Lětopis 39: 1: 142-147.

Šatava, Leoš. 2005. Sprachverhalten und ethnische Identität. Sorbische Schüler an der Jahrtausendwende. Bautzen: Domowina-Verlag.

Šatava, Leoš. 2006a. Etnická identita, jazykové postoje a recepce kultury u žáků lužickosrbských škol. Český lid 93: 337-348.
Šatava, Leoš. 2006b. Jazyk, etnicita a Lužičtí Srbové. Slovanský přehled 92: 2: 301-312. Šatava, Leoš. 2009. Jazyk a identita etnických menšin. Možnosti zachování a revitalizace. Praha: Sociologické nakladatelství.

Šołta, Jan. 1990. Wirtschaft, Kultur und Nationalität. Ein Studienband zur sorbischen Geschichte. Budyšin/ Bautzen: Ludowe nakładnistwo Domowina/Domowina Verlag: 122. Tschernokoshewa, Elka. 2013. „Bin ich Deutscher oder Sorbe?" Wege und Irrwege zu einer hybridologischen Forschungsperspektive in der Lausitz. In: Über Dualismen hinaus. Regionen - Menschen - Institutionen in hybridologischer Perspektive. Tschernokoshewa, Elka - Jacobs, Fabian (eds.). Hybride Welten 6. Münster - New York - München Berlin: Waxmann Verlag: 13-42. Yacoub, Joseph. 1996. Mezinárodní právo a menšiny. In: Menšiny a být menšinou v nejisté Evropě. Praha: Via Europa: 3-11.

Zwahr, Hartmut. 1996. Sprache und Kommunikation innerhalb eines Mikrokosmos. Sechs Befunde zum deutsch-sorbisches Kulturkontext. In: Sprache und Kommunikation im Kulturkontext. Beiträge zum Ehrenkolloquium aus Anla $\beta$ des 60. Geburtstages von Gotthard Lerchner. Hertel, Volker - Barz, Irmhild - Metzler, Regine - Uhlig, Brigitte (eds.). Frankfurt am Main: Peter Lang: 143-149.

Zwahr, Hartmut. 1997-1998. Die Sorben. Geschichte einer Selbstbehauptung zwischen Reformation und Erstem Weltkrieg. In: Herbergen der Christenheit. Jahrbuch für deutsche Kirchengeschichte. Hein, Markus (ed.). Band 21/22: 49-68. 